\title{
Low-duse ursodeoxycholic acid prsiongs cholesterol nucleation time in gallbladder bile of patients with cholestersl gallstones
}

\author{
Dieter Jüngst '. Gerhard Brencter', Ekkehard Pratschke ${ }^{2}$ and Gustay Paungartner ${ }^{i}$

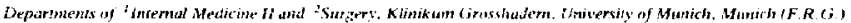

(Receised 2I April I9KX)

(Acceplé 11 Augus! 19k8)

\section{Summary}

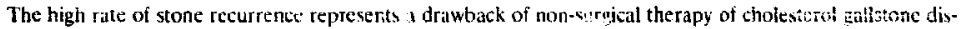

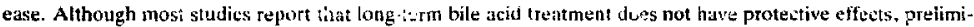
niry results suggest that Iow-dose ursodeoxycholic acid decreases the rute of gallstone recurrence in a subgroup of younger patients. To clarify the underlying mechanism we investiguted whether low-dose ursodeoxycholic acid treatment influences biliary sholesterol saturation and/or nucteation lime nf cholesterol. Ten patients with cholesterol galistones and functioning gallbladdet recejved $250 \mathrm{mg}$ ursodeonycholic acid/day at bedtime $6-10$ days pror to cholecystectomiy. Eliven patients with cholesterol gallstones without treatment served as controls. Choleste: il cr; stals were present in the gallbladder hile of 7 out of the 10 patients receiving ursodeoxycholic acid and in all controi biles. Uritdcoxycholic acid treatment significunily $(P<0.02)$ decreased the cholestern satu-

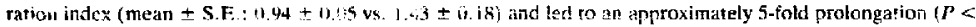
$0.0015)$ of ine cholesterol nucleation time (mean \pm S.E.: $12.0 \pm 2.4$ vs. $2.3 \pm 0.7$ days). We conclude that lowdose ursudeoxycholie acid might be effective in the prevention of post-dissolution gallstone reuarrence by bot't focreasing cinnlesterol saturation and prolongng cholesterol nucleation time.

\section{Introduction}

Several studies have shown thal supersatur. : ion of hile with chotesierol and a rapid formation of citolesterol crystals play a key role in the pathogenesis of cholestesil gallstones [ $1-8]$.

Dissolution of the siones within the galth! adder can be achieved by oral administration of chenodeoxyciclit acis! (CDCA) [9-11], ursodcoxycholic acid (UDCA) or a combination of both [12-15]. More r.:cent studies have shown that extracorporeal shockwave lithotripsy combined with bile acid therapy for fragment dissolution is a safe and effective treatment in sclected patients with tadiolucent galistones

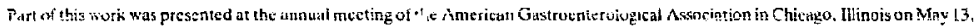
1987 and appeared in abstract form in Gast rcenterolugy $1487: 92: 17+2$.

Correspondence: Dietct Jüngst. M.D., Dept. of Interncl Me ticine It. Klinikum Grosshadern. Murchioninistr. 15, 8000 Mainchen 70 , F.R.G. Tel. $(49-89) 7(1) 5-2 ; ; 3$ 
\{15.17\}. However, supersituration of bile and a reduced murleation time of cholesterol persist in most patients afier stone dissolution and contribute to stone ricusionce vinition has been observed at a rate of about $10 \%$ per year during the first years $[18-20]$ Oral administration of low-dose CDCA has been showii not to be cffective in the preventien of stone recurrence after successful litholytic therapy [21]. However, preliminary resulrs suggest that low-dose UDCA decreases the rate of gallstone recurrence in a subgroup of younger paticrts [22].

To slarify the undelying mechanism we investigaied whether inw-dose UDCA treatment influences biliary cholesterol saturation and/or nucleation timc in patiunts with cholesterol gallstones.

\section{Materials and Mcthods}

\section{Patients and collection of bile}

Tweniy onc patients who underwent elective cholecystectomy becilse of symptomatic gallstones were selected for the study. Cut of the entire peptation undergoing cholecystectomy the patients of the study were selected according to the following criteria: functioning gallbladder documented by visualizatiun of ine gailbladder ty oral cholecystography or sciniigraphy within 6 weeks prior to surtery and cholesterol conzent of the removed siones above $60 \%$. Ten patients. 1 females and 1 male, with a mean age of 50.8 years (range: $23-68$ years) and a mean bodyweight of $66.0 \mathrm{~kg}$ (range: $47-90 \mathrm{~kg}$ ) were treated 6-10 days pricr w chntecystectomy with $250 \mathrm{mg}$ UDCA per diay given at bedtime. Eleven patients, 7 females and 4 males, with a mean age of 46.2 years ( $\mathrm{ran}=: 9.79$ years) and a mean bodyweight of 68.0 $\mathrm{kg}$ (range: $48-89 \mathrm{~kg}$ ) served as control: Gallbladder bile was aspirated during surgery by puncture of the gailbtadtler after ligation of the cystic duct using a sterile needic and syringe. Particular care was taken to collecl gatloladuter bile completely, in order to avoid effects of stratification [23]. The stones were remived with the gallbladder, washed, and analyzed for cholesterol contem. The mean cholesterol content of the stones $(71.3 \%$ v. $76.8 \%)$ was not signifi- cartly diffuen hetween tha grougs of patients.

\section{Biliary microscopy}

After collection, bilt samples wry-mixed thoroughly and one drop was immediately examined by polarized light microscopy for cholesterol crystils. Because small numbers of crystais might be overlooked by the micioscopic examination of unspun bile, the sediment of the bile samples was re-examined for cholesterol crystals after ultracentrifugation (100 $000 \times g$ for $2 \mathrm{~h}$ ).

For the determination of cholesterol nucleation time $4 \mathrm{ml}$ of gallbladder bile were centrifuged for $2 \mathrm{~h}$ at 1000 (h) $\times g$ in a Beckman $L 50$ ultracentrifuge (Beckman Instruments, Fullerton, CA. U.S.A.) to obtain erystal-free bile as described by Holan et al. [2]. The top 1 ul was discarded and the next $2 \mathrm{ml}$ (interplase] were removed by aspiration. An aliquot of the interphase was immediately eatamined microscopically to confirm the absence of crystals; the rest was placed in sterile tubes. flushed with nitrogen. sealed and incubated at $37^{\circ} \mathrm{C}$. Twice daily for up to 3 weeks the interphase was investigated for the appearance of cholesterol crystals. The interval between time zero and the first detec ion of a cholesterol crystal in the sample wis taken as the nucleation time.

\section{Analysis of blie}

For analysis of bile iipids, duplicate aliquots were stored at $-40{ }^{\circ} \mathrm{C}$ prior to determination. Cholestercl was determined colorimet ically after extraction with petroleum ether [24]. Phospholipids were measured using the colorimetric assay of Fiske and SubbaRow [25] and total bile salts were determined by a modified $3 a$-hydroxysteroid dehydrogenase meihod [26]. The saturation index of each sample was calculated by dividing the cholesterol concentration by the maximum chulesterol soiubiu: according to Carey [27]

Individual bile acids were determined by capillary gas liquid thromatography. A 20-m polyethylene gl; col 20000 column (i.d. $0.32 \mathrm{~mm}$ ) and hydrogen as carrier gas were used [28]. The gas chromatograph was a Carlo Erba 4160 model with an on-columin injection system and flame ionization detection (detec- 


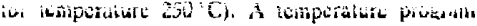
$\left(60-240^{\circ} \mathrm{C}, 30^{\circ} \mathrm{C} / n\right.$ is) $)$ allowed an optimaj injectic: technique. Quantitation was verformed using an internal standard (hyodecxycholic acid) and a multipoint calibration obtained with a Spectra Pbysics SP4100 integrator plotter. Sample preparation included enzymatic hydrolysis of glycine and taurine conjugores and extracts on with diethyl etl,er after acidificacation to $\mathrm{pH} 1$ with concentrates hydrechloric acid. The free acids were methylated using an acidified (pHl 1) mixture of methanol and 2.2-dimethoxypropane $(1: 1 \mathrm{v} / \mathrm{y})$ and trimethyl silylated with a mixture of hexamethyldisilasane and trimethylchlorosilane in pyridine $(2: 1: 3 \mathrm{v} / \mathrm{v})$ at room temperature for $30 \mathrm{~min}$.

\section{Statistical analysis}

The results are expressed as mean $t$ standard er. ror of the mean (S.E.). Th. Student t-test was applied to assess the statistical significance of differences berween means. A $P$ value of $<0.05$ was considered statistically signiiicant.

\section{Resilts}

Biliary micmscopy and cholesterol nucleation time

Cholesterol crystals were present in the native bile in 7 out of 1\% patients under UDCA therapy and in ail biles of the 11 control patients. This cholesterol atscleation time was significantty $(P<0.005)$ fonger ( $12.04 \pm-1.40$ vs. $2.35 \pm 0.72$ days) in patients recciving low tose UDCA that in antreated controk. The single values are given in Tables 1 and 2 .

\section{Biliary lipid composition}

The single values of both groups for totul bile acids, phopholipids, cholexterol, total lipids and the cholesterol saturaion index (CSI) in the gailsladder biles are displayed in Tables 1 and 2 . Statistiral a nâiysis of the data revealed significantly $(P<0.05$ ) higner values of total bile acids $(94.88 \pm 9.27$ vs $70.54 \pm 4.78 \mathrm{mmol} / \mathrm{l})$ and significantly $(P<0.02)$ lower CSi (0.94 \pm 0.05 vs. $1.43 \div 018$ ) in subjects treated with LDCA compared to controis. No significant difference between the groups could be obtained for billary phospholipids, cholesterol or total lipids.

\section{Iidividual bile acids}

The mblar percentages of individuai bile acids in galtbladder bile of both groups of patients are compared in Fig. 1. The relative amount of CDCA was significantly $(P<0.001)$ lower in pacients receiving UDCA while cholic, deoxycholic and lithosholic acid

TABLE ]

CMMPOITION AND CHOLESTEROL :UCLEATION TI-AE OF GALLBLADDER BILES OF 10 PATIENTS UNDER

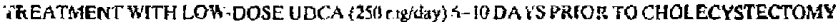

\begin{tabular}{|c|c|c|c|c|c|c|c|}
\hline Patuent & Age (yrs) & $\begin{array}{l}\text { Nuclcation } \\
\text { time (days) }\end{array}$ & $\begin{array}{l}\text { Bite acids } \\
\text { (mmolif) }\end{array}$ & $\begin{array}{l}\text { Phospholipids } \\
\text { (minol/t) }\end{array}$ & $\begin{array}{l}\text { Chotesteral } \\
\text { (mmolit) }\end{array}$ & $\begin{array}{l}\text { Tocal lifios } \\
\text { (g/dl) }\end{array}$ & $\operatorname{Csi}$ \\
\hline $\mathbf{E . K}$ & 6ी & 4.3 & 43.0 & 16.3 & 2.9 & 1.5 & 1) .69 \\
\hline A.S. & 57 & 21.0 & 52.2 & 13.0 & 4.5 & 3.8 & 1.27 \\
\hline X.A. & 61 & 3,9 & 11.3 .9 & 39.0 & 13.1 & 9.2 & 1.06 \\
\hline M.A. & $\$ \$$ & 3.9 & $181 ? ?$ & 68.5 & 14.9 & 14.8 & 0.68 \\
\hline $\boldsymbol{\theta} \mathbf{R}$ & \pm & 5.0 & 81.5 & 34.0 & 7.7 & 7,1 & 0.81 \\
\hline R.E. & 35 & 16.6 & 88.4 & 38.0 & 11.3 & 7.7 & 1.07 \\
\hline $\mathbf{K} . \mathbf{S}^{2}$ & 63 & 20.0 & 105.8 & 40.3 & 9.7 & 8.7 & 0.82 \\
\hline 1.0. & 50) & 3.8 & 83.5 & 32.5 & 7.0 & 6.9 & 0.78 \\
\hline ]. $P$. & 68 & 21.0 & 95.4 & 44.5 & $\pm t i$ & 8.5 & 1.14 \\
\hline US & 36 & 21.0 & 148.0 & 69.0 & 19.2 & 13.4 & 0.95 \\
\hline Mcan \pm S.E. & $50.8 \pm 4.4$ & $12.0 \pm 2.4$ & $94.9 \pm 9.3$ & $39.5 \pm 5.8$ & $19.4 \pm 1.4$ & $8.1 \pm 0.9$ & $0.96 \pm 0.15$ \\
\hline
\end{tabular}

- No choles terol crystals in biic.

CSI = cholesterol saturation index. 
TABLF 2

COMPOSITION AND CHOLESTEROL NUCLEATION TIME OF GALLBLADDER BILES CF !I PATIENTS WITH G'HO-

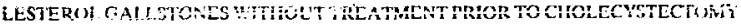

\begin{tabular}{|c|c|c|c|c|c|c|c|}
\hline Patient & Age (yrs) & $\begin{array}{l}\text { Nucleation } \\
\text { [me (A ys) }\end{array}$ & $\begin{array}{l}\text { Hile acick } \\
\text { (mmol/l) }\end{array}$ & $\begin{array}{l}\text { Phospholipids } \\
\text { (inmol/1) }\end{array}$ & $\begin{array}{l}\text { Cinolesterol } \\
(\mathrm{mm}) \mathrm{l} / \mathrm{l})\end{array}$ & $\begin{array}{l}\text { Total lipids } \\
\text { (g/dl) }\end{array}$ & CSI \\
\hline K.M. & 36 & 1.8 & 68.2 & 27.5 & 10.0 & 5.9 & 131 \\
\hline U.G. & 19 & 1.8 & 85.1 & 25.5 & 10.6 & 6.5 & 1.28 \\
\hline 11.3. & 64 & 11.9 & 46.5 & $2 k, 1$ & 7.0 & 4.7 & 1.17 \\
\hline F & 6] & 1.8 & 756 & 28.0 & 24.3 & 6.8 & 2.64 \\
\hline N.L. & 58 & 3.9 & 50.6 & $\$ 7.5$ & 13.7 & 62 & 1.57 \\
\hline F.N. & 46 & 8.9 & 66.5 & 24.5 & 19.1 & 5.90 & 2.44 \\
\hline liA. & 53 & 2.7 & 749 & 20.0 & 5.0 & 5.5 & 0.85 \\
\hline A.A & $2 y$. & 16.8 & $87 \%$ & 33.0 & 8.t & 7.5 & 0.89 \\
\hline T.H. & 79 & 11.6 & 52.2 & 28.0 & 7.5 & 5.0 & 1.15 \\
\hline R.R. & 35 & 0.7 & (rit) & 420 & 12.0 & 6.9 & 1.32 \\
\hline B. $w$ & 29 & 1.9 & 99.2 & 67.0 & 17.4 & $10 . i$ & $\mathrm{i} . \mathrm{i} 4$ \\
\hline Mean \pm S.E. & $+6.2 \pm 5.5$ & $2.3 \pm 0.7$ & $70.5 \pm 4.8$ & $32.8 \pm 3.8$ & $122 \pm 1.8$ & $6.5 \pm 0.5$ & $1.43 \pm 0.18$ \\
\hline
\end{tabular}

were not significantly different. As expected, the percertage of UDCA in bile was much higher (18.5 \pm 3.2 vs. $2.7 \pm 0.9 \%$ ) under the administration of IDCA.

Correlation of nuteation tinte to $\mathrm{CSI}$, biliary lipitis and age

No correlations were found between the cholesterol nucleation time and the CSI (Fig. 2), the total lip-

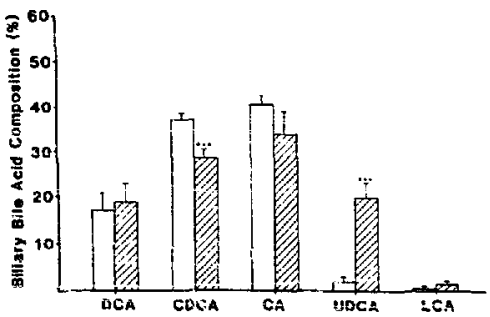

Fin. B. R̈thative : mounts of individuai bile acids (mean \pm S.E.) in gallhladder bite of patients with riolesterol gallstones: onen bass. controls: hatched bass, under treat'icent with $250 \mathrm{mg}$ ? day UDCA 6-10 days pror 10 choles atecho iy. **P<0,001. DCA, deoxychutic acid; CA cholic acid: LCA, lithocholic acid. ids, total bile acids, phospholipids, cholesierol and age in patients receiving UDCA and control slibjects.

\section{Discussion}

In our study we administered a short-lerm treat-

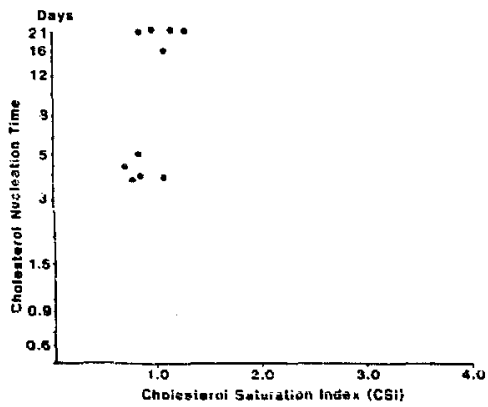

Fig. 2. Correlation of CSI and cholesterol nucleation time in gallbladder bile of patients with cholesterol gallstones: $(0)$ control patients; (O) patients under treatment with $250 \mathrm{mg} / \mathrm{day}$ UDCA i- 10 days prior to rbolecystectomy. 
ment with a low UDCA dose $(250 \mathrm{mg} /$ day given at bedtime) in patients who were referrec to the surgical cepartment for tective cnoiecystectomy because of symptomatic gallstones. Drug compliance was documented by measurentents of elevaled UDEA. concentrations in gallbladder bile in all treated patients, In patients under UDCA treatment the percentage of UDCA in bile was higher (mean: $18.5 \mathrm{vs}$. $2.7 \%$ ) than in control biles.

These findings are similar to the results of Stiehl et al. [29]. who reported a mean relative amount of $28 \%$ of UDCA in cholecystokinin-stimulated ducivenal bile of patients receiving $250 \mathrm{mg}$ UDCA/day. The higher biliary percentage of UDCA in their study might be caused by the much longer Ireatment period of 3 months as compared to $6-10$ days in our investigation. The period of ireatment with UUCA may have been too short to achieve a steady state at the time of bile sanipling. The mean proporitons of cholic (32 vs. $25 \%$ ), chenodeoxycholic (28 us $31 \%$ ). deoxycholic (i9 vs. $16 \%$ and litiocholic (1.5 vs. $1.8 \%$ ) acid were similar in both st 1 'iles.

Compared to controls. UDCA-tredted patients revealed a significantly higher mean concentration of

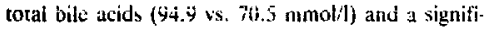
canily lower mean (S) (0.94 vs. 1.43). In 6 patients receiving UDCA a CSI below i was calculated; the remaining 4 were slightly supersaturated. Cholesterol monohydrate crystals were detected in 7 of the 10 patients. There was no clear relation between the presance of crystals and the CSI. In one hile with the highest degree of suturation (1.27) no cholesterol crystals were found and two biles with the lowest CSI

\section{References}

I Sedaghat A.. Grundy SM. Cholesterol crystals und the formation of chulesterol gallstones. $N$ Engt I Med $[980$; 302 : 1274-1277.

2 Helan KR, Hotzbach KT, Hermann RE et al. Nucleation time: key lactor in the rathogenesis of chclesterol छalistone disease. Gastusent: ology 1979: 77: 711-717.

3 Gollish SH, Burnstein Mj, Itson RG, et ai. Nucleation of chultwisral monohydrate crystals from hepatic and gallbladder bile of paticnts with cholesterol gall wnes. Gut 1983:24: $836-844$

4 Burnstein MH. Ilson RG. Petrunka CN. ct al. Evidence for a putent nucleating factor in the gallbladder bile of patient: values (6.6) s:u $0.7 \times)$ contained multiple crystals (Taile $\mathrm{i}$ ).

Aithougn the number of crystai-containing biles was similar in UDCA-ireated patients (7/10) and in untreated controls $(11 / 11)$ there was a strikitig difference in the cholesterol nucleation timc between ithe grow.ps. The mean cholesterol nucleation time in biles from (IDCA-troted paticats ( 12 uays) was ahout 5 fold longer than in control biles $\{2.3$ days). These findings indicate that even short-term treatment with low-dose ULCA has i beneficial effect on the rapid cholesterol crystallisition in gaibladder bile of patients with cholesterol gallstones. The results are in agreement with the long-term clinical study of Vilianova et al. [22], who showed that low-dose UDCA (30) $\mathrm{mg} /$ day) might prevent gallstone recursace after succesful stonc dissolution in a subgroup of juluger patients.

Our sidta suggest that the armitistration of low. dose UDCA may have a protective : ffect against the recurrence of gallstones after successful disswiuticn therepy. This short-term study shows favourable alterations of both cholesterol saturation and cholesierct nuclention time of gailbladder bile and shoulat stimulate further long-term clinical studies to substantiate these results.

\section{Acknowledgement}

The authors are grateful to Mrs. Benedikta Zündt and Mrs. Elke Konig for their skillful technical assistance.

with cholesterol gallstines, Gastiantuterology 198\%; 8.5; $801-807$.

5 Sdmirand WH. Small DM. The physicuchemical basis of cholexicrol gallstone formation in man. 1 Clin Invest 1968 ; 47: $1043-11152$.

6 Carey MC. Smail DM. The physical chemistry of cholesterol solubility in bile. J Cliw Invest 1978; 61: 998-1026.

7 tave FF. Smith BF. L.tMont JT. Human gallbladder mucin accelertics nucleation of cholesterol in artificial bile. Gastroenterology 1984; $67: 27 i-275$.

8 Green AK, Ottenhoff R, Noordam C, $z$ i cerhondt FMJ, Hock FJ, Tytgat GNJ. Clolesterol nucleation pronoting activity shifts cholesterol (CH) and phospholipid (PL) from the micellar to the vesicular phase in model bilt i $A^{\text {horracil. }}$ 
Gastronterology 1987:92: 1737.

"7 Dowling RH. Chenudeoxycholic acid ther apy of gatsicnes. Clin Gistroenterol 1977; 6 ; 141-16.9.

10 Thiste JH. Hofmann AF, Ot DJ. Stcphens DH. Cheñ therapy for galtsione dissolution. i. Éficicay and safety. JAMA 1978: $230: 194 !-1446$

It Schoenfitit $L, L$ achin JM. The Stefing Committee, The National Cooperative Gallsione Stady Group. Chenodiol (chenodeoxysholk acid) for diss'ylution of gallstones: The National Croperntive Gu!!stone Sudy. A controfted study of cfficacy and sifely. Ann Intern Med 198t:45:257-2x2.

12 Tokyo Cooperative Gallsione Study Group. Efficacy and indications of ursodeoxychclic acid treatment for dissolving gallstones. A multicenter double hlind trial. Gastroenter (ology 1980: 78 : $5+2-548$.

13 Tin: GS, Saien G, Coli: itlu, $A_{w}$, et al. Ursodenycholic acid: a salc and effective agent for dissolving cholesterol gallstones. Ann Inteta Mzd 19g2: $97: 351 \cdots 354$

14 Bachrach WH. Hofinann $A . \vec{r}$. Ursodeoxycholic acid in the Ireatmòn nf cholesterol cholc'ithiasis. Dig Dis Sci 1982: 27 : $7,37-761,833-856$

15 Rochrkasse R. Fromm H. Malavolti M., Tuntuguntla AK, Ceryak S. Gallstone disoolution treatment with a combination of chemodeoxycholic and ursodeoxycholic acids. Stud-

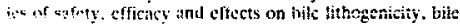
acid ponl and serum lipids. Dig Dis Sci 1986; 31: $11132-1040$.

16 Sauerbruch T. Delius M. Paumeariner. G. et al. Fragmenmation of gallsioncs ty exiracorporeal shock waves, N Engl J Med 1986: 314: 818-822.

17 Sackmann M. Detits M, Situchtuch 1 , el al. Shock-wave lithotripsy of gallhladder stones. N Engl J Med 1085; 31 ; $393-397$

Is Dowling RH, Giew in D, IEupm ar. Murphy GM, The

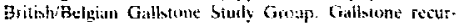

rence and posi-diswolulioss manaperent In: Paumgartner G, Stiehl A, Gerok W. eds. Enterohepatic Cirsujaijon sí Bile Acids and Sterot metabotism. Fatk Symposium 42 . Lancaster: MijP Press. 1985: 361-385.

19 Lanzini A. !azı a wi RP, Kupfer RRi. et al. Gallsinne reeurrence after metiy i dissolution. An overeshmated lintat? I Hepatol 1986; ? 21!-246.

20 O'Donnel LDJ. Jeaton KW. Recurrenec and is reati rence of gall stolies atter medical dissollition: a longterm follow up. Gut 1988: 29: 655-658.

21 Matks IW, Lan SP. The Steering Committe. Low dose chcnubioj to prevent galtstone recurrence after dissolution therapy. Ans fintern Med 1984; 100: $37,-381$.

22 Villanova $N$, bazzoli F. Trabbani $R$, ot al. Gallstone recuirenec aftei succes ful oral bile acid treatment: a follow-up study and evatuation of long term posi-dissolution treatment [Absiract]. Gastruenterology 1987: 92: 1789.

23 Tera $H$. Stratilicaticni ui numan gallbladder bilv in vivo Acra Chir Scand 1960); Ziv: (suppl) 4-85.

24 Abell LL, Levy BB. Brodic BR, Kendall FE. A simplified method for the estimation of totai cholesterol in scrims and demonstration of its specificity. J Biol Chem 1952; 195 : 357-366.

25 Fiske CH. Subiakow Y. The colorimetri determination uf phusphorus. I Binl Chem 1925: 66: $375-40$.

26 Talalay $P$. Enzymatic anatysis of steroid inoinones. Biuchem Anal 1960; : : 119-143.

27 Cury MC. Critich tables for calculating ine chointeroi saturation of native bile. J Lipid Res 1978: 19:945-955.

28 Karlaganis (6. Paumgartner 6 Determination ol ible acids in scium by capillary gas-liquid chrometography. Clin Chim Acta 197!: $42: 19-26$.

29 Stichl A, Ravdsch R. Rudulph E. Watter S. Effect of ursodeoxycholic acid on biliary bile ncid and bile lipid ccmpositum in gatistome paticnts. 1 kepatology 1984: $107-111$ 